\title{
EFFECT OF PARBOILING PROCESS ON MILLING QUALITY, PHYSICAL AND CHEMICAL PROPERTIES OF TWO RICE VARIETIES
}

\author{
M. A. El-Bana, R. A. Goma and A. S. Abd El-Sattar \\ Crops Technology Department, Food Technology Research Institute, Agricultural \\ Research Center, Al-Giza, Egypt.
}

Received: May 13, 2020

Accepted: Jun. 8, 2020

\begin{abstract}
The present study was carried out to investigate the effect of parboiling process on physicochemical, nutritional properties, Milling quality and organoleptically of brown and white rice. The obtained results revealed that, physical properties of brown and white rice varied from one variety to another. Giza 182 rice variety was significantly the longest length among Giza 179 rice variety. In addition, parboiling process had no effect on the length and width of either brown or the white rice at $P \leq 0.0^{\circ}$.The paddy rice of raw (Giza 179) had the highest percentage of broken grains and the lowest percentages of head rice and Brown rice as compared with (Giza 182) variety, where parboiling process led to decrease the percentage of broken rice from 32.40 to $4.28 \%$ for Giza 179 and from 16.50 to 5.50 for Giza 182.In addition, parboiling process help to increase the head rice and white rice percentages. Water uptake, sedimentation value of white rice were significantly higher than that of brown rice. white rice variety of Giza $\mathbf{1 7 9}$ had the lowest cooking time among all of the tested rice samples (17 min.). water uptake and sedimentation values decreased as a function of parboiling process but cooking time increased for all rice samples. Gel consistency (GC) varied significantly among varieties in both brown and white rice. Alkali spreading value in brown rice varieties showed lower values in comparing with white rice varieties. white rice variety of Giza 182 had the highest Alkali spreading value, Elongation and Amylose content among the other varieties. Moreover, it were decreased upon subjecting rice to parboiling process. Brown rice of two rice varieties had higher contents of crude protein, ether extract and ash but lower content of total carbohydrates than those of white rice. Parboiling process lowered the percentage of the crude protein and ether extract in both brown and white rice .whereas، it increased the ash and minerals content in white rice samples. The cooked white rice of Giza 182 variety had the highest mean scores for the palatability characteristics among all of the tested rice samples. In addition, parboiling process helped to decrease the mean score for the palatability characteristics but the values were still acceptable by the panelists.
\end{abstract}

Key words: Parboiling process, physical and chemical properties, milling quality, cooking quality, brown and white rice.

\section{INTRODUCTION}

Rice (Oryza sativa, L.) is one of the most important staple food crops of the world. More than two thirds of the world relies of nutritional benefit of rice. In Egypt, rice is considered as one of the most essential field crops, not only as a food crop, but also a land reclamation crop and for exportation. (Jing et al., 2008).
Egypt is the largest producer of rice in Africa, In 2014, the production of rice in Egypt was 6.00 million tons. Egypt recorded the second yield in the world (3.86 tons/acre) per year during the years 2010-2014 (FAO/UN, 2016). Rice is considered as one of the major source of nutrients, consisting of carbohydrates, proteins, fats, fibers, minerals, vitamins, 
etc. and is consumed daily in the form such as bread, noodles and parboiled rice (Heinemann et al., 2005 and Swasdisevi et al., 2010). Brown rice is the whole grain rice obtained from unpolished rice. It is an excellent source of nutrients such as protein, dietary fiber, fat, minerals and vitamins (Abd El-Sattar et al., 2016). The physicochemical characteristics include grain length (L), grain breadth (B), L/B ratio, hulling and milling percentage. The cooking qualities are amylose content, alkali spreading value, water uptake, volume expansion ratio and kernel elongation ratio. Grain quality is a very wide area encompassing diverse characters that are directly or indirectly related to exhibit one quality type (Siddiqui et al., 2007). The quality of milled parboiled rice is being assessed based on physical parameters like degree of milling, percentage head rice, broken grain, chalkiness, red streak grain, grain size, color, shape and 1000 grains weight (Abdelhady et al., 2014). In order to obtain rice kernel suitable for consumption, paddy undergoes dehulling to shear off the hull and milling to remove the bran and germ. These activities affect the physicochemical and cooking quality of rice (Jinorose et al., 2014). Milling quality has been evaluated on the basis of head rice turnout, total milling recovery and has been considered as important criteria from marketing point of view. Brokens produced during milling are generally the result of immature, chalky or fissured kernels, all of which are weak and typically break during milling due to the substantial forces imparted to kernels in order to remove bran (Siebenmorgen et al., 2013). Pusa Basmati 1121 has gained popularity due to its extra long slender length $(8.3 \mathrm{~mm})$, leading to higher breakage during milling operation and hence reduced milling yield (Kale et al.,2015). It was hypothesised that such breakage can be reduced by following parboiling treatment to the paddy before milling operation to harden the rice kernel in order to increase head rice recovery. Parboiling process is involved the partial boiling of rice paddy following steaming the hydrated paddy for $25 \mathrm{~min}$ followed by drying to $14 \%$ moisture content before dehusking and polishing (Ndindeng et al., 2015).During boiling, the gelatinization occurs only in the outer layers of aleurone part and seals the grain hence the head rice yield improved. (Boers et al., 2015). Furthermore, Parboiling treatment has been reported to cause significant qualitative changes in the rice, affecting its physical, chemical characteristics and nutritional composition (Manful et al., 2008 and Patindol et al., 2008). The objectives of this study are to investigate the effect of parboiling process on physicochemical, nutritional properties, milling quality and cooking quality of brown and white rice.

\section{MATERIALS AND METHODS}

\section{Materials:}

Two varieties of Egyptian rice (Oryza sativa L.) namely Giza 179 (short grain Indica/Japonica) and Giza 182 (long grain Indica) were employed in this study, These samples were obtained from Rice Research and Training Center (RRTC) at Sakha, Kafr El-Sheikh Governorate, Egypt during the season of 2019, under the recommended conditions for date of culture, fertilization, harvesting time and irrigation.

\section{Methods :}

\section{Preparation of parboiled paddy rice :}

Parboiled rice were prepared by using Giza 179 and Giza 182 varieties following the procedure of Singh et al. (1999) and modified by boiling the samples at $100{ }^{\circ} \mathrm{C}$ 
for 20 minutes, then steaming under pressure $(1.5 \mathrm{~kg} / \mathrm{cm} 2)$ at $121{ }^{\circ} \mathrm{C}$ for 15 minutes. Parboiled rice was dried in an air oven at $55{ }^{\circ} \mathrm{C}$ until constant weight was reached.

\section{Physical characteristics:}

The grain physical attributes namely, grain dimension (length and width), grain shape (grain length to width ratio) and grain index were measured. Grain dimensions $(\mathrm{mm})$ were measured using a micrometer with accuracy of $0.001 \mathrm{~mm}$ where 10 uniform rice grains were randomly selected and their length and width were measured in duplicate (Suwansri and Meullenet, 2004). Grain shape of rice was carried out by dividing the grain length by width for ten grains that were taken randomly as reported by Ahuja et al. (1995). The 1000 grain from each variety of rice were counted randomly in triplicate, weighed separately and estimated as grain index $(\mathrm{g} \mid 1000 \mathrm{~g})$ as reported by Khush et al. (1979). Bulk density of rice was determined according to the method of Myklestad et al. (1968).

\section{Milling Characteristics:}

One hundred and fifty gram of cleaned rough rice varieties Giza 179 , Giza 182, parboiled Giza 179 and parboiled Giza 182 were taken randomly. They were dehulled using Asatake Laboratory Dehuller. The total milled rice, brown rice, hulls, heads and broken percentages were calculated using the procedure of Khan and Wikramanayake (1971).

\section{Water uptake, sedimentation} values at $77^{\circ} \mathrm{C}$ and $82^{\circ} \mathrm{C}$ and cooking time:

Water uptake, sedimentation values and cooking time of brown, milled, parboiled brown, parboiled milled rice varieties were determined following to procedures of Simpson et al. (1965).
Determination of cooking and eating quality:

Alkali spreading value was determined according to the method described by Bhattacharya and Sowbhagya (1980). Gel consistency (GC) was determined according to the method described by Cagampang et al. (1973). Elongation percentage was measured using the method of Tomar (1985). Amylose content was measured according to Juliano et al. (1981) procedure.

\section{Chemical composition of rice samples:}

Moisture, crude protein, ether extract and ash contents were determined according to the methods of A.O.A.C. (2005). Total carbohydrates content was calculated by subtracting protein, ash, and ether extract from total mass of $\mathbf{1 0 0}$ as reported by A.O.A.C. (2005).

\section{Determination of minerals:}

Rice samples were prepared for mineral determination according to the method of the A.O.A.C. (2005). Total phosphorus (P) was determined by ascorbic acid technique using the colorimetric method that described by Murphy and Riley (1962). Potassium (K) and sodium $(\mathrm{Na})$ contents of rice samples were estimated using flame photometer as given by Pearson (1976). Iron (Fe), Copper (Cu), Zinc $(\mathrm{Zn})$ and Calcium (Ca)contents of rice samples were conducted using the atomic absorption spectrophotometer Perken Elmer Model 2180 and following the methods of Pearson (1976).

Organoleptic evaluation of rice samples :

Organoleptic evaluation of cooked raw, parboiled and quick cooking brown and white rice were subjected to their 
organoleptic qualities. Samples were served to panel of 10 judges. The panelists were asked to evaluate colour, flavour, taste, texture and overall acceptability on a 1 to 10 hedomic scale as described by Farag et al. (1996). A score 1 being (dislike extremely) and 10 being (like extremely).

\section{Statistical analysis :}

Data of physical properties, chemical determination and organoleptic evaluation were subjected to analysis of variance and the means were further tested using the least significant difference test (LSD) as outlined by Stell and Torrie (1980).

\section{RESULTS AND DISCUSSION}

\section{Physical and Technological Properties of Rice Samples:}

Uniformity in shape and size is considered the first quality characteristic. Milled rice has been classified into four categories on the basis of the average length $(\mathrm{mm})$ of the kernels. Extra long ( > 7.50), Long (6.61 - $7.50 \mathrm{~mm}$ ), Medium $(5.51-6.60 \mathrm{~mm})$ and short $(\leq 5.50 \mathrm{~mm})$, Ahuja et al. (1995). Data presented in Table (1) indicated that the length of raw brown rice grains of the two different studied varieties (Giza 179 and Giza 182) were 5.73 and $7.47 \mathrm{~mm}$, respectively. Whereas the length of raw white rice grains were 5.46 and $7.23 \mathrm{~mm}$ of the previous mentioned varieties . Giza 182 rice variety was significantly the longest among Giza 179 rice variety. The same Table show that, parboiling process had no effect on the length of either brown or the white rice at $P \leq 0.0^{\circ}$. The width of raw brown rice in the two different varieties of rice (Giza 179 and Giza 182) were 2.62 and $2.31 \mathrm{~mm}$, where in case of white rice grains were 2.46 and $2.13 \mathrm{~mm}$, respectively, with no obvious changes in width as a result of parboiling process. Subjecting the previous results to analysis of variance at $P \leq 0.05$ support our findings. These results are in the same trend of those reported elsewhere (Otegbayo et al., 2001; Abd El-Sattar et al., 2016 and Gewaily et al., 2019).

As for Grain shape of the two rice varieties (Giza 179 and Giza 182) for raw brown and white rice were given in Table (1). The recorded differences were significant at $P \leq 0.05$. In addition, no pronounce affect was found upon subjecting different rice varieties to parboiling process. However, grain shape of rice depends on the ratio between length and width as reported by Ahuja et al. (1995). who classified the shape as Slender (> 3.0), Medium (2.1 $3.0)$, Bold (1.1 - 2.0) and Round ( $\leq 1.0)$. The present results are in accordance with those of (Otegbayo et al., 2001; Abd ElSattar et al., 2016 and Gewaily et al., 2019).In addition, the data in the same Table revealed that, grain index (weight of 1000 grains) values of raw brown and white rice for the two rice varieties (Giza 179 and Giza 182) were (29.95 and 26.10 g) and (22.92 and $20.41 \mathrm{~g})$, respectively. It is noteworthy from the same Tables that, parboiling process had no significant effect on grain index, neither for brown nor for white rice grains at $P \leq 0.05$. Similar results were found elsewhere( Otegbayo et al., 2001 and Gewaily et al., 2018). In addition the data in the same Table revealed that, bulk density were higher in white rice samples than those of brown rice. . In addition, pronounce affect was found upon subjecting different rice varieties to parboiling process. Apparent also from the above mentioned data that, milling process led to a pronounced increase of bulk density, where a noticeable decrement in grain index values were recorded. Data in this respect were in agreement with the findings of numerous investigators. (Jiamyangyuen and Ooraikul, 2008 ; ElBana et al., 2010 and Abd El-Sattar et al. , 2016 ). 
Table (1): Some Physical properties of the tested rice varieties.

\begin{tabular}{|c|c|c|c|c|c|c|}
\hline \multirow{2}{*}{ Rice variety } & \multirow{2}{*}{ Treatments } & \multicolumn{2}{|c|}{ Grain dimension } & \multirow{2}{*}{ Grain shape } & \multirow{2}{*}{$\begin{array}{c}\text { "Grain } \\
\text { index (g) }\end{array}$} & \multirow{2}{*}{$\begin{array}{l}\text { Bulk density } \\
\text { (g/cm3) }\end{array}$} \\
\hline & & $\begin{array}{l}\text { Length } \\
(\mathrm{mm})\end{array}$ & $\begin{array}{l}\text { Width } \\
(\mathrm{mm})\end{array}$ & & & \\
\hline \multirow[t]{2}{*}{ Giza179 } & Brown & $5.73^{\mathrm{c}}$ & $2.62^{\mathrm{a}}$ & $2.19^{d}$ & $29.95^{\mathrm{a}}$ & $0.66^{f}$ \\
\hline & $\begin{array}{l}\text { Parboiled } \\
\text { Brown }\end{array}$ & $5.70^{c}$ & $2.64^{\mathrm{a}}$ & $2.16^{d}$ & $29.99^{\mathrm{a}}$ & $0.69^{\mathrm{e}}$ \\
\hline \multirow[b]{2}{*}{ Giza179 } & White & $5.46^{d}$ & $2.46^{b}$ & $2.22^{\mathrm{C}}$ & $26.10^{b}$ & $0.74^{d}$ \\
\hline & $\begin{array}{l}\text { Parboiled } \\
\text { White }\end{array}$ & $5.49^{d}$ & $2.49^{b}$ & $2.20^{c}$ & $26.31^{b}$ & $0.76^{\text {cd }}$ \\
\hline \multirow[b]{2}{*}{ Giza182 } & Brown & $7.47^{\mathrm{a}}$ & $2.31^{\mathrm{c}}$ & $3.23^{b}$ & $22.92^{c}$ & $0.76^{\mathrm{bc}}$ \\
\hline & $\begin{array}{l}\text { Parboiled } \\
\text { Brown }\end{array}$ & $7.50^{\mathrm{a}}$ & $2.33^{\mathrm{c}}$ & $3.22^{b}$ & $22.94^{c}$ & $0.78^{b}$ \\
\hline \multirow[b]{2}{*}{ Giza182 } & White & $7.23^{b}$ & $2.13^{d}$ & $3.39^{a}$ & $20.41^{d}$ & $0.81^{\mathrm{ab}}$ \\
\hline & $\begin{array}{l}\text { Parboiled } \\
\text { White }\end{array}$ & $7.24^{b}$ & $2.15^{d}$ & $3.37^{a}$ & $20.49^{d}$ & $0.84^{a}$ \\
\hline
\end{tabular}

${ }^{*}$ Each value was an average of ten determinations .

+Values followed by the same letter in column are not significantly different at $P<0.05$.

"Grain index = weight of 1000 grains.

\section{Milling characteristics of some rice varieties:}

Data presented in Table (2) indicated that the hulls percentage of the two rice varieties (Giza 179 and Giza 182) were 21.10 and $20.40 \%$, respectively, while parboiling treatment decreased the hull percentage in both. Apparent also from the same Table that, the percentages of brown rice were $(78.90$ and $79.60 \%)$ for the two studied rice varieties (Giza 179 and Giza 182), respectively. Parboiling treatment caused an increment in the previous mentioned percentages. These results may be related to the gelatinization and expansion of the grain during steaming step of the parboiling process. In addition, the return to grains natural state by drying are believed to cement the interior fissures or check of the kernels, thus enabling the grains to assume a greater hardness (Jagtap et al., 2008). These results are in line with those of (Abd El-Rassol et al.,2005 ; Chavan et al., 2018 and Gewaily et al., 2019) . Apparent also from the same Table that, total milled rice of the two rice varieties revealed that, samples of Giza 179 showed an increasing in the previous mentioned parameter in comparing with that of Giza 182, while the percentage of the total milled rice increased as a function of parboiling process. This increment may be related to the adhesion between the outer layer of the grain (aleuron layer) and the endosperm. These results are in the same trend of those reported by ( Abd El-Rassol et al., 2005; Ayamdoo et al., 2014 and Chavan et al., 2018). 
M.A.El-Bana, et al.,

Table (2): Milling characteristics of some rice varieties.

\begin{tabular}{|l|c|c|c|c|c|c|}
\hline $\begin{array}{c}\text { Rice } \\
\text { varieties }\end{array}$ & Treatments & Hulls\% & $\begin{array}{c}\text { Brown } \\
\text { rice\% }\end{array}$ & $\begin{array}{c}\text { Total milled } \\
\text { rice\% }\end{array}$ & $\begin{array}{c}\text { Head } \\
\text { rice\% }\end{array}$ & $\begin{array}{c}\text { Broken } \\
\text { rice\% }\end{array}$ \\
\hline Giza179 & Raw & $21.10^{\mathrm{a}}$ & $78.90^{\mathrm{d}}$ & $72.0^{\mathrm{b}}$ & $39.60^{\mathrm{d}}$ & $32.40^{\mathrm{a}}$ \\
\hline Giza179 & Parboiled & $19.60^{\mathrm{c}}$ & $80.40^{\mathrm{b}}$ & $73.10^{\mathrm{a}}$ & $68.82^{\mathrm{a}}$ & $4.28^{\mathrm{d}}$ \\
\hline Giza182 & Raw & $20.40^{\mathrm{b}}$ & $79.60^{\mathrm{c}}$ & $68.70^{\mathrm{d}}$ & $52.20^{\mathrm{c}}$ & $16.50^{\mathrm{b}}$ \\
\hline Giza182 & Parboiled & $18.60^{\mathrm{d}}$ & $81.40^{\mathrm{a}}$ & $70.80^{\mathrm{c}}$ & $65.30^{\mathrm{b}}$ & $5.50^{\mathrm{c}}$ \\
\hline
\end{tabular}

*Each value was an average of three determinations.

+Values followed by the same letter in column are not significantly different at $P<0.05$.

Head rice recovery of paddy is inversely proportional to broken percentage recovery as low broken percentage in the sample leads to high head rice recovery (Chavan et al., 2016). The percentages of head and broken rice varied according to the length and width of the rice varieties as given in Table (2). The indica/Japonica rice variety (Giza 179) had higher percentages of broken rice than those of Indica rice variety (Giza 182). Parboiling process led to increase the percentage of the head rice regardless to the used rice varieties (Giza 179 and Giza 182). The head rice percentage increased from 39.60 to68.82 for Giza 179 and from 52.20 to $65.30 \%$ for Giza 182. Remarkable reduction was observed in broken rice percentage upon subjecting the tested rice varieties to parboiling treatment, especially in case of variety Giza 179 . Such decline varied from 32.40 to $4.23 \%$ for Giza 179 and from 16.50 to 5.50 for Giza 182 . reversible relationship was recorded between head rice percentage and percentage of broken rice. This may be attributed to the increase in hardness of the rice grain that occurred following parboiling process, which play an active rule in improving the head rice yields and hardness values. These results are in agreement with those found by (Abd ElRassol et al.,2005; Ibukun, 2008 Abd ElSattar et al., 2016; Chavan et al., 2018 and
Zohoun et al., 2018). Furthermore, broken rice percentages have been used as means of detecting varietal differences in the varieties under investigation. Also this parameter may considered as an index for the quality of rice varieties.

Water uptake, sedimentation value, Cooking time and Cooking and eating quality of two tested rice varieties:

Results given in Table (3) show that, water uptake values of $77^{\circ} \mathrm{C}$ and $82{ }^{\circ} \mathrm{C}$ were higher in white rice samples than those of brown rice ones. This may be related to the removal of protein, lipids and minerals in brown rice samples. Abd El-Sattar et al., (2016) found that, water uptake could be easily bound by carbohydrate compared to lipid or protein. Apparent also from the same Table that, water uptake whether at $77^{\circ} \mathrm{C}$ or $82{ }^{\circ} \mathrm{C}$ decreased as a function of parboiling process for all rice samples. Furthermore white rice variety of Giza 182 had relatively the highest water uptake value at $77^{\circ} \mathrm{C}$ and $82{ }^{\circ} \mathrm{C}$ among all of the tested rice samples. The obtained results are in line with those reported by (Ayamdoo et al., 2014; Abd El-Sattar et al., 2016 ; Chavan et al., 2018 and Gewaily et al., 2019). Apparent also from the same Table Table (3) that, Sedimentation values at $77^{\circ} \mathrm{C}$ and $82{ }^{\circ} \mathrm{C}$ 


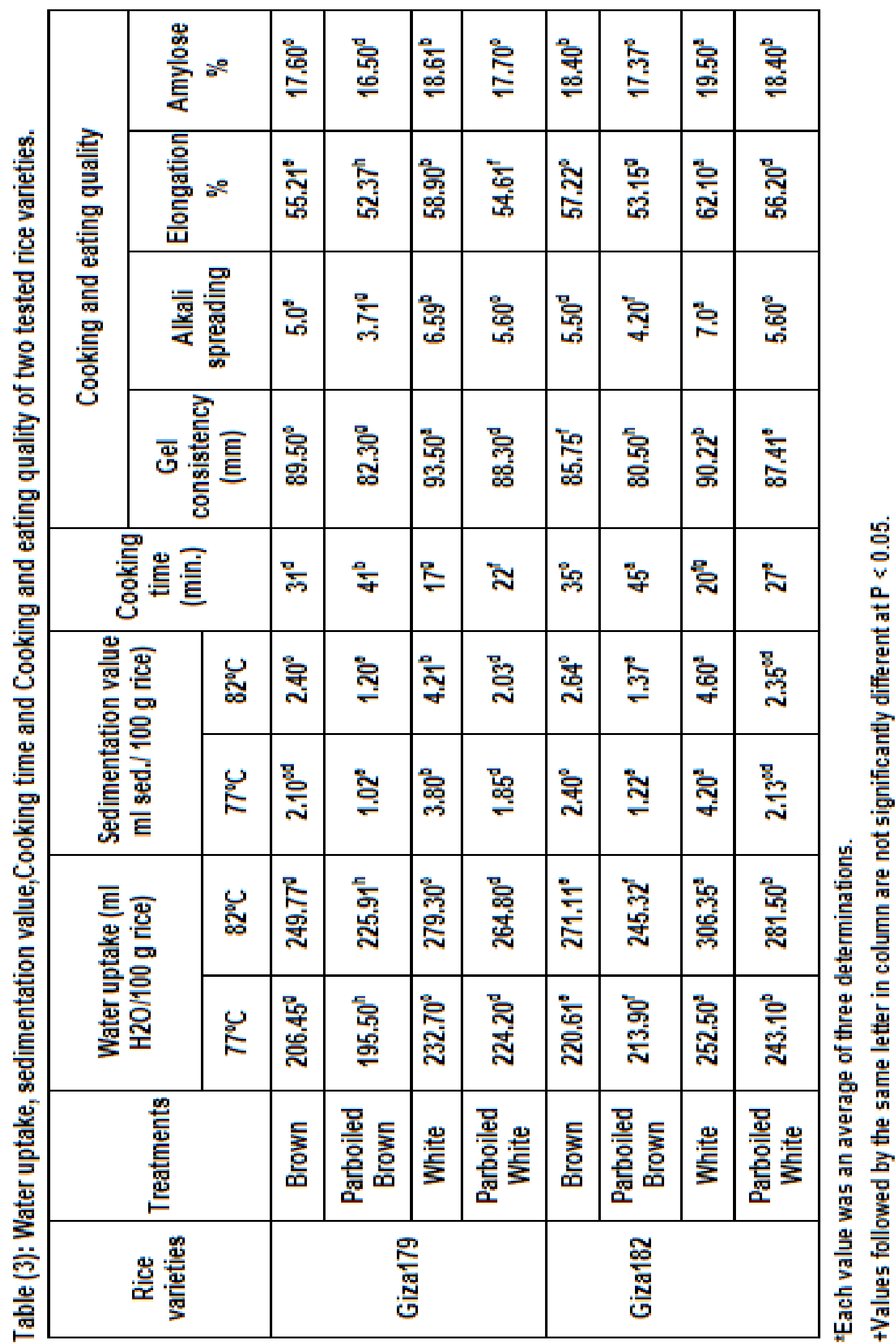


were higher in white rice samples than those of brown rice. Furthermore, sedimentation values at $82{ }^{\circ} \mathrm{C}$ were higher than those of $77^{\circ} \mathrm{C}$ for different rice varieties. Considerable reduction was recorded upon subjecting the different rice varieties to parboiling process and the reduction in sedimentation values that occurred at 82 ${ }^{\circ} \mathrm{C}$ was higher than that at $77{ }^{\circ} \mathrm{C}$. However, (Soponronnarit et al., 2006) found that, Decrease in the gruel solid loss was attributed to the stronger structure of rice imparted by gelatinization of starch. Moreover, parboiled brown rice variety of Giza 179 had the lowest sedimentation value among all of the tested rice varieties (1.02 and $1.20 \mathrm{ml}$ sed. $/ 100 \mathrm{~g}$ rice) at $770 \mathrm{C}$ and $820 \mathrm{C}$, respectively.. The obtained values are found to be in the range that reported elsewhere ( Otegbayo et al., 2001; Saeed et al., 2001; Abd El-Sattar et al., 2016 and Chavan et al., 2018). The cooking time is the time needed to make the opaque central portion of the rice grain disappear completely during cooking (Itagi and Singh, 2015). The data in the same table revealed that, brown rice had cooking time higher than that of milled rice. In addition, cooking time increased as a function of parboiling process for all rice samples. Furthermore parboiled brown rice variety of Giza 182 had relatively the highest cooking time among all of the tested rice samples (45 $\mathrm{min}$.)..While, white rice variety of Giza 179 had the lowest cooking time among all of the tested rice samples (17 $\mathrm{min}$.). The obtained results were in line with those reported by ( Abd El-Sattar et al., 2016 ; Chavan et al., 2018 ; Zohoun et al., 2018 and Gewaily et al., 2019).

Alkali spreading value is used as an inverse indicator of gelatinization temperature of rice starch granules. The gelatinization temperature is the temperature at which the starch granule begins to swell irreversibly in hot water with a simultaneous loss of crystallite (Irshad, 2001). Results of the alkali spreading value are given in Table (3). Alkali spreading value in brown rice of the two tested varieties showed lower values in comparing with white rice varieties. As for brown rice, it seems to require a longer time to cook. Moreover, the alkali spreading values decreased after subjecting the two mentioned rice varieties to parboiling process. These results may be due to the variation in terms of processing conditions for the rice varieties as clarified by (Takano, 1980) .Who reported that, The resistance of parboiled rice to disperse in the alkali test may be related to the hardness of the grain as a result of the retrogradation that take place in gelatinized starch. The white rice of the two tested varieties (Sakha 179 and Giza 182) had the highest values for alkali spreading values compared to the other rice samples. The obtained results are in agreement with those reported by (Derycke et al., 2005; El-Bana et al., 2007 and Zohoun et al., 2018).

Gel consistency of rice are classified as hard (26 to $40 \mathrm{~mm}$ ); medium (41 to 60 $\mathrm{mm}$ ) and soft (61 to $100 \mathrm{~mm}$ ) as reported by Cagampang et al. (1973). Data presented in Table (3) show that, gel consistency in brown rice decreased in comparing with white rice. Moreover, gel consistency content decreased after subjecting the brown and white rice to parboiling process. parboiled brown rice variety of Giza 179 had the lowest gel consistency content $(82.30 \mathrm{~mm})$ in comparing with the other rice samples. Generally, all varieties classified under soft rice which ranged between 61$100 \mathrm{~mm}$ as described by Cagampang et al. (1973). Perez (1979) concluded that GC of milled rice or rice starch was a good measurement of gel viscosity which in turn was an index for the texture of cooked rice. Because of the relationship between gel viscosity and amylograph 
consistency, the last can be used as a tool for rapid screening of eating quality in a rice breeding program. These results are in accordance with those found by (EI-Bana et al.,2007; Abd El-Sattar et al., 2016 and Wafaa K. Galal et al., 2019). Elongation percentages defined as the ratio of length of cooked rice grain to the length of milled rice grain (El-Kady, 1992). The elongation percentages of cooked rice presented in Table (3) show higher values for white rice than brown rice and long grain variety (Giza 182) than that of short grain variety (Giza 179) for all treatments. This was expected because of the large amount of water that added to long grain samples. Moreover, the elongation percentage of white rice of the Giza 182 variety was the highest among all of the studied rice samples. Moreover, it was decreased upon subjecting rice to parboiling process. Hardness of rice seems to correlated negatively with its elongation percentage. The results are in accordance with those of (El-Bana et al., 2007; Gewaily et al., 2019and Wafaa K. Galal et al., 2019). Amylose content has an important role in determination of cooking, eating and pasting properties of rice (Asghar et al., 2012). Data presented in Table (3) also indicated that, milling was considered one of the major factors that helped to increase the amylose content of rice varieties. Hence, white rice grains of Giza 182 variety contained the highest amount of amylose content $19.5 \%$. Where parboiled brown rice of Giza 179 variety had the lowest value $16.5 \%$. On the other hand, parboiling process caused a reduction in amylose content of all samples. The obtained results are in agreement with those reported by (Kale et al., 2015 and Yenrina et al., 2017).

\section{Chemical composition of some rice varieties:}

Data presented in Table (4) showed that, the moisture content of brown and white rice varieties ranged between 11.93 to $12.83 \%$. Furthermore, moisture content of brown rice grain for the two tested rice varieties were lower than those of white rice. These values are in line with those of (Abd El-Sattar et al., 2016). Apparent also from the same Table that, slight increases, were occurred as a function of parboiling treatment in both brown and white rice varieties. Crude protein, Ether extract and ash tended to decrease with the milling for the two tested rice varieties this could be explained by the removal of the embryo and bran layers therefore crude protein, ether extract and ash found in this parts will be decreased. From the same Table, it could be observed that, crude protein content in brown rice Giza179 variety had the highest level of crude protein $9.83 \%$, while the lowest value was recorded in parboiling white rice of Giza182 variety $(7.80 \%)$. Parboiling process caused a reduction in crude protein content of different rice varieties. This could be related to the leaching out that take part of the non protein nitrogen, albumin and rupturing of molecules during steaming as reported by (Chavan et al.,2018).On the other hand, (Chukwu and Oseh, 2009)suggested that, the slight reduction of protein content is caused by dissolution of soluble nitrogenous compounds during the soaking step of parboiling process. Results of the same Table also revealed that, there were high significant differ in ether extract between brown and white rice of the same variety, also between the different varieties. Brown rice of Giza 182 variety contains a relatively high level of ether extract content $(2.97 \%)$, while parboiling white rice of Giza 179 variety had the lowest level of ether extract content (0. $0.66 \%$ ). Parboiling process caused a reduction in the ether extract content in both brown and white rice varieties. These results 
could be attributed to the effect of parboiling process whereas, the oil of the kernel travels to its surface, hence the bran will contain a higher percentage of oil and endosperm in turn will lose its oil (Abd El-Rassol et al., 2005 and lbukun, 2008). In addition to ,increased temperature and pressure during steaming can be implicated in leaching and breaking of oil globules (Heinemann et al., 2005 ; Paiva et al., 2015 and Chavan et al.,2018). Ash content has an important role in the determination of mineral content of rice ( Bhat and Sridhar, 2008). High significant differences in ash content was recorded between the varieties as well as between brown and white rice in the same variety. Moreover Brown rice of Giza 179 variety had the highest level of ash content (1.64\%). Furthermore, an increment was recorded as a function of parboiling process of milled rice. In contrast ash content of parboiled brown rice was decreased. The increase in ash content of parboiled milled rice may be due to the water soluble mineral salts which penetrated throughout the grain during soaking and steaming process (Ibukun,2008; Chukwu and Oseh 2009 Chavan et al.,2018 and Isnaini, et al., 2019).

The data presented in the same Table showed that, the white rice variety of Giza 182 had the highest carbohydrates content in comparing with the other tested samples. In addition, carbohydrates content of rice samples was increased as a result of milling. These results may be due to the removal of the embryo and bran layer, to yield milled rice poor in fat, crude protein, fiber and ash. So, the level of available carbohydrates will be higher in milled rice than in brown rice (Moongngarm and Saetung 2010). On the other hand, parboiling process has effect on carbohydrate content of Brown rice. Results obtained were in agreement with (Abd El-Rassol et al., 2005). Furthermore, (Thomas et al., 2013 and Chavan et al.,2018) they reported that, parboiled rice can be considered as the good source of energy as higher carbohydrate content.

Table (4): Chemical composition (\%) of some rice varieties.

\begin{tabular}{|l|l|c|c|c|c|c|}
\hline $\begin{array}{c}\text { Rice } \\
\text { varieties }\end{array}$ & \multicolumn{1}{|c|}{ Treatments } & Moisture & $\begin{array}{c}\text { Crude } \\
\text { protein }\end{array}$ & $\begin{array}{c}\text { Ether } \\
\text { extract }\end{array}$ & Ash & $\begin{array}{c}\text { Total } \\
\text { carbohydrate }\end{array}$ \\
\hline \multirow{2}{*}{ Giza 179 } & Brown & $11.93^{\mathrm{e}}$ & $9.83^{\mathrm{a}}$ & $2.75^{\mathrm{c}}$ & $1.64^{\mathrm{a}}$ & $85.78^{\mathrm{f}}$ \\
\cline { 2 - 7 } & Parboiled Brown & $12.62^{\mathrm{ab}}$ & $9.64^{\mathrm{a}}$ & $2.63^{\mathrm{d}}$ & $1.44^{\mathrm{c}}$ & $86.29^{\mathrm{e}}$ \\
\hline \multirow{2}{*}{ Giza 179 } & White & $12.24^{\mathrm{cd}}$ & $8.69^{\mathrm{b}}$ & $0.75^{\mathrm{g}}$ & $0.67^{\mathrm{g}}$ & $89.89^{\mathrm{b}}$ \\
\cline { 2 - 7 } & Parboiled White & $12.83^{\mathrm{a}}$ & $8.52^{\mathrm{b}}$ & $0.66^{\mathrm{h}}$ & $0.84^{\mathrm{e}}$ & $89.98^{\mathrm{b}}$ \\
\hline \multirow{2}{*}{ Giza } & Brown & $12.01^{\mathrm{de}}$ & $8.72^{\mathrm{b}}$ & $2.97^{\mathrm{a}}$ & $1.57^{\mathrm{b}}$ & $86.74^{\mathrm{d}}$ \\
\cline { 2 - 7 } & Parboiled Brown & $12.42^{\mathrm{bc}}$ & $8.47^{\mathrm{b}}$ & $2.85^{\mathrm{b}}$ & $1.38^{\mathrm{d}}$ & $87.30^{\mathrm{c}}$ \\
\hline \multirow{2}{*}{ Giza } & White & $12.08^{\mathrm{de}}$ & $8.02^{\mathrm{c}}$ & $0.95^{\mathrm{e}}$ & $0.58^{\mathrm{h}}$ & $90.45^{\mathrm{a}}$ \\
\cline { 2 - 7 } & Parboiled White & $12.22^{\mathrm{cd}}$ & $7.80^{\mathrm{c}}$ & $0.84^{\mathrm{f}}$ & $0.78^{\mathrm{f}}$ & $90.58^{\mathrm{a}}$ \\
\hline
\end{tabular}

Each value was an average of three determinations.

+Values followed by the same letter in column are not significantly different at $P<0.05$. 


\section{Minerals content :}

Minerals or elements play an important role in human nutrition, some are essential for much component as hem for blood.(National Academy of Sciences, 2001).The ash content of rice varieties was important to some extent, it contained the nutritionally the important minerals. Some of which are shown in Table (5). Potassium content was the highest element among all of the determined mineral contents. In addition, brown rice contained the high mineral contents of the tested rice samples. The results are in agreement with that reported by (Abd El- Rassol et al., 2005 and Abd El-Sattar et al., 2016), They reported that, brown rice had higher ash content than white rice due to high mineral content in its bran layer.

Whereas, parboiling process caused an increasing in most of minerals content of parboiled white rice. On contrast, parboiled brown rice samples seems to show a little decrease in their minerals content. These results are in accordance with those of (Abd El- Rassol et al., 2005 ;
Ibukun, 2008 and Zohoun et al., 2018).They reported that, mineral migrate from outer layers into endosperm during parboiling treatments.

\section{Organoleptic Evaluation of Rice Samples :}

Organoleptic evaluation of different varieties of brown and white rice samples are presented in Table (6). The data indicate that cooked white rice surpassed in colour when compared with cooked brown, parboiling cooked rice regardless to rice variety. Cooked white rice of Giza 182 and Giza 179 had the highest values of colour among all of the tested varieties. Generally, it should be noted that parboiling of paddy rice caused a decrement in the colour value of cooked brown and white rice. These results could be attributed to the effect of parboiling process on husk pigments, amylase activity during soaking of paddy rice and the accumulation of some fractions that result from starch degradation.

Table (5): Mineral contents of some rice varieties.

\begin{tabular}{|c|c|c|c|c|c|c|c|c|}
\hline \multirow{2}{*}{$\begin{array}{c}\text { Rice } \\
\text { variety }\end{array}$} & Treatment & \multirow{2}{*}{$\mathrm{P} \%$} & \multicolumn{6}{|c|}{ (mg/100g) } \\
\cline { 4 - 9 } & & & $\mathrm{K}$ & $\mathrm{Na}$ & $\mathrm{Ca}$ & $\mathrm{Fe}$ & $\mathrm{Zn}$ & $\mathrm{Cu}$ \\
\hline \multirow{2}{*}{ Giza 179 } & Brown & 0.26 & 183.22 & 23.22 & 27.9 & 1.87 & 1.50 & 0.75 \\
\cline { 4 - 9 } & Parboiled Brown & 0.23 & 183.10 & 23.01 & 27.5 & 1.75 & 1.51 & 0.71 \\
\hline \multirow{2}{*}{ Giza 179 } & White & 0.15 & 90.21 & 9.51 & 13.7 & 1.20 & 1.11 & 0.56 \\
\cline { 4 - 9 } & Parboiled White & 0.21 & 94.58 & 10.00 & 16.8 & 1.41 & 1.10 & 0.58 \\
\hline \multirow{2}{*}{ Giza 182 } & Brown & 0.21 & 174.80 & 24.40 & 26.31 & 1.50 & 1.12 & 0.58 \\
\cline { 2 - 9 } & Parboiled Brown & 0.19 & 174.61 & 24.15 & 26.0 & 1.45 & 1.11 & 0.84 \\
\hline \multirow{2}{*}{ Giza 182 } & White & 0.12 & 85.54 & 8.50 & 12.60 & 1.22 & 0.80 & 0.39 \\
\cline { 2 - 9 } & Parboiled White & 0.17 & 89.65 & 8.99 & 15.70 & 1.35 & 0.77 & 0.45 \\
\hline
\end{tabular}


M.A.El-Bana, et al.,

Table (6): Effect of parboiling processing on the organoleptic properties of cooked brown and white rice varieties.

\begin{tabular}{|l|c|c|c|c|c|}
\hline \multirow{2}{*}{ Rice varieties } & Treatment & Colour & Flavour & Texture & $\begin{array}{c}\text { Overall } \\
\text { acceptability }\end{array}$ \\
\hline \multirow{2}{*}{ Giza 179 } & Brown & $7.8^{\mathrm{cd}}$ & $7.6^{\mathrm{bc}}$ & $8.5^{\mathrm{ab}}$ & $7.97^{\mathrm{bc}}$ \\
\cline { 2 - 6 } & Parboiled Brown & $7.5^{\mathrm{d}}$ & $7.2^{\mathrm{c}}$ & $8.2^{\mathrm{ab}}$ & $7.63^{\mathrm{c}}$ \\
\hline \multirow{2}{*}{ Giza 179 } & White & $8.7^{\mathrm{ab}}$ & $8.3^{\mathrm{ab}}$ & $8.1^{\mathrm{b}}$ & $8.36^{\mathrm{ab}}$ \\
\cline { 2 - 6 } & Parboiled White & $8.1^{\mathrm{bcd}}$ & $7.8^{\mathrm{bc}}$ & $8.5^{\mathrm{ab}}$ & $8.13^{\mathrm{bc}}$ \\
\hline \multirow{2}{*}{ Giza 182 } & Brown & $8.1^{\mathrm{bcd}}$ & $7.9^{\mathrm{bc}}$ & $8.2^{\mathrm{ab}}$ & $8.06^{\mathrm{bc}}$ \\
\cline { 2 - 6 } & Parboiled Brown & $7.8^{\mathrm{cd}}$ & $7.6^{\mathrm{bc}}$ & $8.4^{\mathrm{ab}}$ & $7.93^{\mathrm{bc}}$ \\
\hline \multirow{2}{*}{ Giza 182 } & White & $9.2^{\mathrm{a}}$ & $8.9^{\mathrm{a}}$ & $8.4^{\mathrm{ab}}$ & $8.83^{\mathrm{a}}$ \\
\cline { 2 - 6 } & Parboiled White & $8.5^{\mathrm{bc}}$ & $8.2^{\mathrm{b}}$ & $8.8^{\mathrm{a}}$ & $8.50^{\mathrm{ab}}$ \\
\hline
\end{tabular}

*Each value was an average of ten determinations .

+Values followed by the same letter in column are not significantly different at $P<0.05$.

The Flavour is a combination of the taste and smell and it is the main criterion that makes the product to be liked or disliked, while tasting is influenced by the flavor and it is one of the most essential factors of product acceptability ( Durgrao, et al., 2017). In addition, the same Table showed that, parboiled brown and white rice decline slightly in their flavour when compared with cooked brown and white rice. Furthermore, cooked white rice variety of Giza 182 had the highest values of flavour in comparing with all of the other rice samples.

As for texture of different cooked rice samples, it should be noted that, texture of parboiled brown and white rice were little bit better than those of cooked brown and white rice. white rice (Giza 179 variety) had the lowest texture value in comparing with all rice samples. parboiling leads to development of some unique aromatic and textural characteristics that are appealing to certain groups of consumers (Demont et al., 2012). The mean scores of overall acceptability for cooked rice samples revealed that the acceptability of parboiled brown rice variety of Giza 179 had the lowest score among all of the cooked rice samples. These results were found to be true since, the raw cooked white rice had better properties (colour, flavour, texture and overall acceptability) in comparing with the other rice samples (brown, and parboiling rice).

\section{REFERENCES}

Abdelhady, S., D. Borello, A. Shabanand F.Rispoli(2014).Viability study of biomass power plant fired with rice straw in Egypt. The ${ }^{6}$ th.International Conference on Applied Energy - ICAE. Energy Procedia.,61: 211- 215.

Abd El-Rassol, E.A., Sahar R. Abd ElHady and M.A. El-Bana (2005). Effect of parboiling and milling processing on chemical composition and some nutritional values of two rice varieties. J. Agric. Sci. Mansoura Univ., 30(12): 7781-7788. 
Abd El-Sattar, A.S., M.A. El-Bana and Somaya M. Morsy (2016). Physical properties, chemical and technological evaluation of waxy and non waxy rice. Minufiya J. Agric. Res., 34(3):1119-1138.

Ahuja, S.C., D.V. Panwar, U. Ahuja and K.R.Gupta (1995). Basmati rice: The scented pearl, pp. 1-61. Hiusar, Haryana, India: Directorate of Pub., CCS Har-yhana Agricultural University.

A.O.A.C. (2005). Association of Official Analytical Chemists. Official Methods of Analysis. ${ }^{18}$ th Ed., Washington D.C., USA.

Asghar, S., F. M. Anjum, M. R. Amir and M. A. Khan (2012). Cooking and eating characteristics of rice (Oryza sativa L.)- A review. Pak. J. Food Sci., 22: 128-32.

Ayamdoo, A. J.,B. Demuyakor, Saalia, F. K. and Francis, A. (2014). Effect of varying parboiling conditions on cooking and eating/sensory charactoristics of Jasmine 85 and Nerica 14 rice varieties. Am. J. Food Tech., 9(1) : 1-14.

Bhat, R. and K. R. Sridhar (2008). Nutritional quality evaluation of electron beam-irradirated lotus (Nelumbonucifera) seeds. Food Chem., 107: 174-84.

Bhattacharya, K.R. and K. Sowbhagya (1980). Size and shape classification of rice, Riso, 29: 181-185.

Boers, H. M.,H. J. Seijen and D. J. Mela (2015). A systematic review of the influence of rice characteristics and processing methods on postprandial glycaemic and insulin aemic responses. British J. of Nutrition, 114 (7).1035-1045.

Cagampang, G.B., C.M. Perez and B.O. Juliano (1973). A gel consistency test for eating quality of rice, J. Sci. Food Agric., 24: 1548-1594.

Chavan, P., S. R. Sharma, T. C. Mittal, G.
Mahajan and S. K. Gupta (2016). Optimization of parboiling parameters to improve the quality characteristics of pusa Basmati 1509. J Food Process Engg doi:10.1111/jfpe.12454.

Chavan,P., S. R. Sharma, T. C. Mittal, G. Mahajan and S.K. Gupta (2018). Effect of parboiling technique on physicochemical and nutritional characteristics of basmati rice. Agric Res. J., 55 (3) : 490-499.

Chukwu, O. and F. J. Oseh (2009). Response of nutritional content of rice (Oryza sativa) to parboiling temperature. Am. Eurasian J. Sustain Agric 3: 381-87.

Demont, M., E. Zossou, P. Rutsaert, M. Ndour, P. Vanmele and W. Verbeke (2012). Consumer valuation of improved rice parboiling technologies in Benin. Food Quality and Preference, 23: 63-70.

Derycke, V., G. E. Vandeputte, R. Vermeylen, W. De Man, B. Goderis, M. H. J. Koch and J. A. Delcour (2005). Starch gelatinization and amyloselipid interactions during rice parboiling investigated by temperature resolved wide angle $X$-ray scattering and differential scanning calorimetry. J. of Cereal Science, 42, 334-343.

Durgrao, M.N.V., H. W. Deshpande and I. H. Syed (2017). Studies on suitability of Indian rice variety for preparation of instant rice. J. of Pharmacognosy and Phytochemistry, 6 (6): 1425-1429.

El-Bana, M.A., Hanan A. Kassab, M.R.ElDeen and A.Ghazi (2007). Effect of some storage conditions on the physical and technological proprieties of raw, parboiled and quick cooking rice. J. Agric., sci. Mansoura Univ., 32 (4): $2673-2689$.

El-Bana, M. A., W. K. Galal and S.T. ElHadidie (2010). Physico- chemical and technological studies on some Egyption rice varieties. J. of Food and 
Dairy Sci., 1 (4): 161 -172.

El-Kady, A.A. (1992). Grain quality evaluation for some Egyptian rice varieties, Research Fellowship Report, IRRI, Philippines.

FAO/UN. (2016). FAOSTAT database: http://faostat3.fao.org/home/index.html.

Farag, S. A., A. El-Shirbeeny and A.E. Nassef (1996). Physicochemical studies for preparing quick cooking rice by using gamma irradiation, Annals of Agric. Sci., Moshtohor, 34(2): 641-652.

Gewaily, E.E., Amera T. Mohammed and W.T. Abd El-Rahem (2019). Effect of Different Irrigation Regimes on Productivity and Cooking Quality of Some Rice Varieties. World Journal of Agricultural Sciences 15 (5): 341-354.

Gewaily, E.E., W. T. Abd El-Rahem, Soheir T. El-Hadide and Maha $M$. Tawfik (2018). Chemical and technological evaluation of some egyptian rice cultivars .Middle East $\mathrm{J}$. Agric. Res., 7(3): 876-886.

Heinemann, R. J. B., P. L. Fagundes, E. A. Pinto, M. V. C. Penteado and U. M. Lanfer-Marquez (2005). Comparative study of nutrient composition of commercial brown, parboiled and milled rice from Brazil. J Food Comp Anal 18: 287-96.

Ibukun, E. O. (2008). Effect of prolonged parboiling duration on proximate composition of rice. Scientific Research and Essay, 3 (7): 323-325.

Irshad, A. (2001).Factors affecting rice grain quality. Cereal Chem., 78(4): 295399.

Isnaini, C., P. Pathomrungsiyounggul and N. Konsue (2019). Effect of preparation method on chemical property of different thai rice variety. J. of Food and Nutrition Research, 7 (3): 231-236.

Itagi, H.N. and V. Singh (2015). Status in physical properties of colored rice varieties before and after inducing retrogradation. J. Food Sci. Tech., 52(12): 7747-7758.

Jagtap, P. S., R. Subramanian and V. Singh (2008). Influence of soaking on crushing strength of raw and parboiled rice. Int. J. Food Prop.,11: 127-36.

Jiamyangyuen, S. and B.Ooraikul (2008). Thephysico-chemical, eating and sensorial properties of germinatedbrown rice. J. Agric. And Environmental, 6 (2): 119-124.

Jing, Q., B. Bouman, H. van Keulen, H. Hengsdijk, W. Cao and T. Dai (2008). Disentangling the effect of environmental factors on yield and nitrogen uptake of irrigated rice in Asia. Agricultural System. 98(3):177188.

Jinorose, M., S. Prachayawarakorn and S. Soponronnarit (2014). A novel imageanalysis based approach to evaluate some physicochemical and cooking properties of rice kernels. J. Food Eng., 124: 184-90.

Juliano, B. O., C. M. Perez, A. B. Blakeney, D. T. Castillo, N. Kongseree, B. Laignelet, E. T. Lapis, V.V. S. Murty, C. M. Paule and B. D. Weeb (1981). International cooperative testing on the amylose content of milled rice . Starch/Staerke .33:157-162.

Kale,S. J., S . K. Jha, G. K. Jha, J. P. Sinha and S. B. Lal (2015). Soaking induced changes in chemical composition, glycemic index and starch characteristics of Basmati rice. Rice Sci., 22: 227-36.

Khan, A. U. and V. E. A. Wikramanayake (1971). A laboratory test tube miller, IRR. Agric. Eng. Dept. pp: 71-80. (Typescript).

Khush, G. S., C. M. Pauke and N.M. Delacruze (1979). Rice grain quality evaluation and improvement, Proceeding of the Workshop on Chemical Aspects of Rice Grain 
Quality, IRRI, pp. 390, Los Banos, Philippines.

Manful, J. T., C. C. Grimm, J. Gayin and R. D. Coker (2008). Effect of variable parboiling on crystallinity of rice samples. Cereal Chemistry, 85: 92-95.

Moongngarm, A. and N. Saetung (2010). Comparison of chemical compositions and bioactive compounds of germinated rough rice and brown rice Food Chem., 122 ; 782-788.

Murphy, J. and J. P. Riley (1962). A modified single solution method for determination of phosphate in natural waters, Anal. Chem. Acta., 27: 31-36.

Myklestad, O., E. M. Christie, G. G. Coate and D. J. Mcdonald (1968). Chemical, physical and organoleptic properties of 12 varieties of rice, Division of Food Preservation, Technical Paper, 33: 19. Commonwealth Sci. and Industrial Research Organization, Australia.

National Academies of Sciences, Institute of Medicine (2001). Fruits and vegetables yield less vitamin $A$ than previously thought; upper limits set for daily intake of vitamin $A$ and Nine Other Nutrients, Press Release Jan. 9.

Ndindeng, S. A., J. T. Manful, K. Futakuchi, D. L. Mapiemfu, J. M.AkoaEtoa, J. Bigoga and J. Moreira (2015). A novel artisanal parboiling technology for rice processors in subSaharan Africa. Food Sci. and Nutr., 3(6), 557-568.

Otegbayo, B. O., F. Osamuel and J. B. Fashakin (2001). Effect of parboiling on physico-chemical qualities of two local rice varieties in Nigeria. $J$ Food Tech., Africa 6: 130-32.

Paiva, F. F., N. L. Vanier, J. D. J. Berrios, V. Z. Pinto, D. Wood, T. Williams, J. Pan and M. C. Elias (2015). Polishing and parboiling effect on the nutritional and technological properties of pigmented rice. Food Chem., 191: 10512.
Patindol, J., J. Newton and Y. J. Wang (2008). Functional properties as affected by laboratory-scale parboiling of rough rice and brown rice. J. of Food Sci., 73, 370-377.

Pearson, D. (1976). The Chemical Analysis of Foods, 7th Ed. Churchill, London, U.K.

Perez, C.M. (1979). Gel consistency and viscosity of rice, International Rice Research Institute (IRRI). pp. 292.

Saeed, F., I. Pasha, F. M. Anjum, H. A. R. Suleria and M. Farooq (2001). Effect of parboiling on physico-chemical and cooking attributes of different rice cultivars. Internet J. Food Safety.13: 237-45.

Siebenmorgen, T. J., P.A. Counce and C. E. Wilson (2013). Factors affecting rice milling quality. Agri Natural Resources FSA2164.

Siddiqui, S.U., T. Kumamaru and H. Satoh (2007). Pakistan rice genetic resources-I: Grain morphological diversity and its distribution. Pak. J. Bot., 39, 841-848.

Simpson, J.E., C. R. Adair, G. R. Kohler, E. K. Dawson, H. J. Deobald, E. B. Kester, J. T. Hogan, O. M. Batcher and J. V. Halick (1965). Quality evaluation studies of foreign and domestic rices, USDA Technol. Bull., 133 p. 185.

Singh, S., M. Kall and S. R. Malhotra (1999). Effect of parboiling, handpounding and machine milling on chemical composition of rice, $\mathrm{J}$. of Food Sci. Tech., 36(5): 434-435.

Soponronnarit, S., N. Adisak, J. Athikom and T. Chaiyong (2006). Parboiling brown rice using superheated steam fluidization technique. J. Food Eng., 75: 423-32.

Stell, R.G. and J.H. Torrie (1980). Principles and Procedures of Statistics, ${ }^{2}$ nd Ed. McGraw-Hill, New York, USA.

Suwansri, S. and J. Meullenent (2004). 
Physicochemical characterization and consumer acceptance by Asian consumers of aromatic jasmine rice. J. Food Sci., 69(1): 30-37.

Swasdisevi, T., W. Sriariyakula, W. Tia and S. Soponronnarit (2010). Effect of pre-steaming on production of partially-parboiled rice using hot-air fluidization technique. J. Food Eng., 96: 455-62.

Takano, H. (1980). Parboiling of rice, Part 1.Parboiling of paddy rice. II- Effect of parboiling on Japonica and Indica rice, Technical Report on Post Harvest Rice, Processing: 1-25. Tropical Agric. Res. Center, Kalsuske. Japan.

Thomas, R., W. A.Wan-Nadiah and R.Bhat (2013). Physiochemical properties, proximate composition, and cooking qualities of locally grown and imported rice varietiesmarketed in Penang, Malaysia. Int. Food Res. J., 20: 1345-51.

Tomar, J.B. (1985). Studies on the inheritance of kernel size and its association with physical and chemical quality characters in rice. $Z$. Pflanzenzucht, 95: 361-366.

Wafaa, K. Galal,R. A. Gomaa and Maha M. Tawfik (2019). Physico-Chemical and Cooking Properties of Some Rice Varieties to Produce Salty and Sweet Puffed Rice . Alex. J. Food. Sci. and Technol., 16 (1) : 21-30.

Yenrina, R., S. D. Ismanto and R. Ummah (2017). The changes on dietary fiber and starch digestibility of various rice varieties from West Sumatera through parboiling process. Research J. of Pharmaceutical, Biological and Chem. Sci., 8 (2): 929-935.

Zohoun, E. V., E. N. Tang, M. M. Soumanou, J. Manful, N. H. Akissoe, J. Bigoga, K. Futakuchi and S. Ndindeng (2018). Physicochemical and nutritional properties of rice as affected by parboiling steaming time at atmospheric pressure and variety. Food Sci. Nutr., 6: 638-652. 
تأثير عملية الغلي على جودة الضرب والتبيضي والخواص الطبيعية والكيماوية لصنفين من الأرز

محمد احمد البنا، رفاعي جمعة على ، عدلي سمير عبد الستار

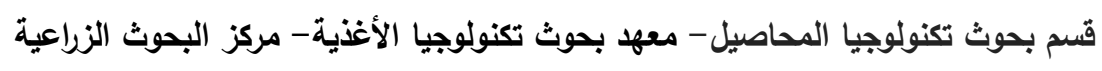

الملخص العربي

أجريت هذه الاراسة لمعرفة تأثير عملية الغلي على الصفات الطبيعية والكيميائية والغذائية وجودة عليتى الضرب والتبييض والصفات العضوية الحسية للأرز البني والأبيض. وأظهرت النتائج ما يلي: والصفات الفضون

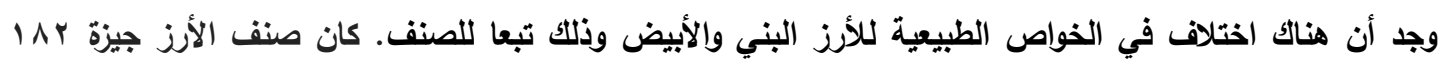

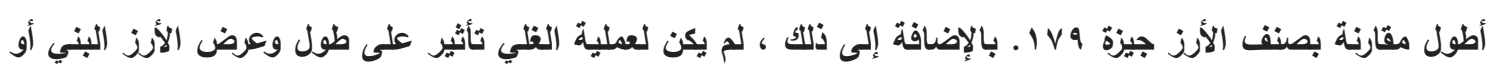

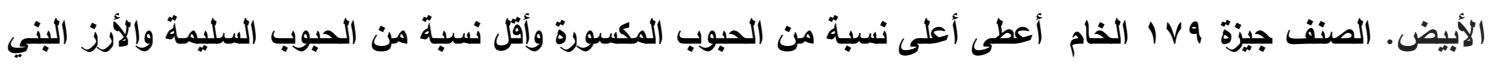

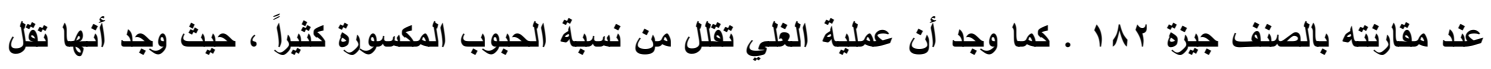

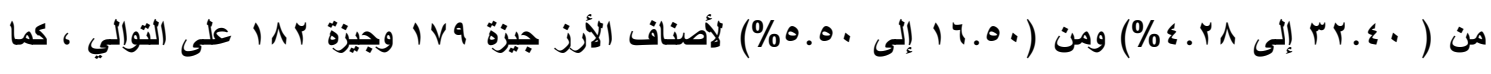

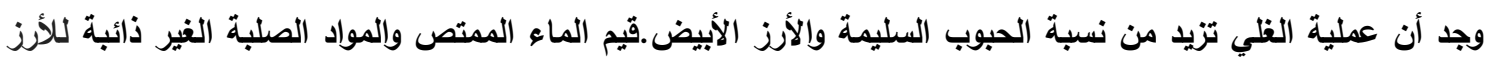

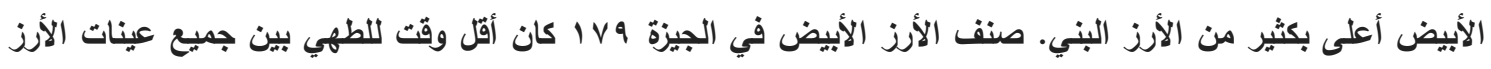

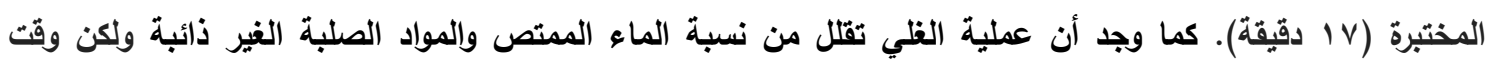

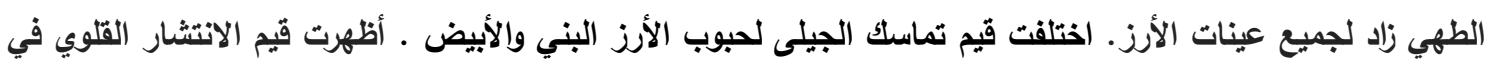

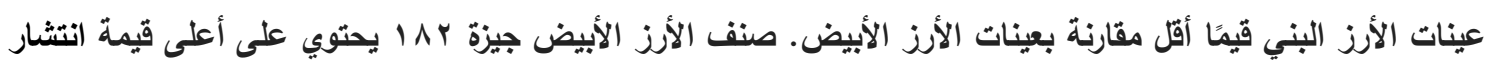

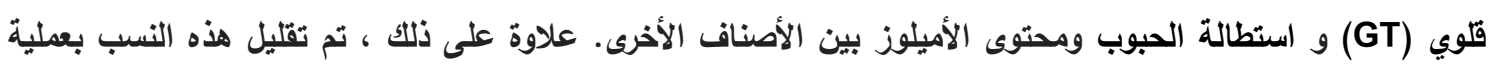

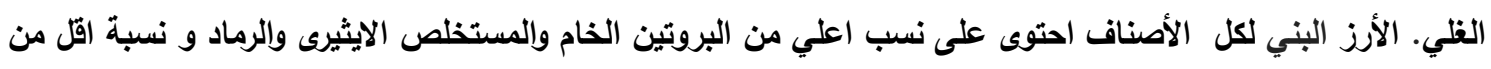

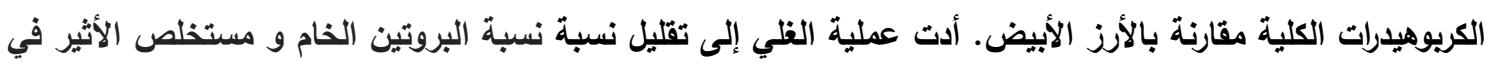

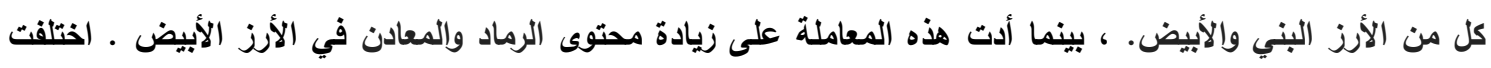

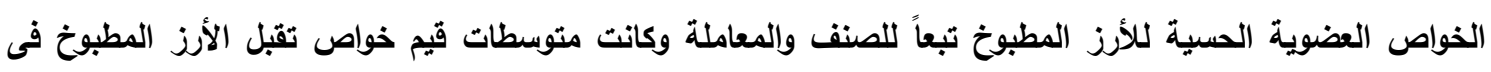

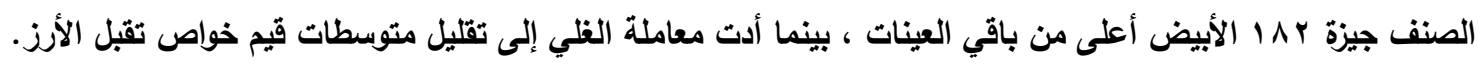

السادة المحكمين كلية الزراعة - جامعة كفر الثيخ

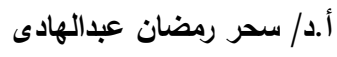
كلية الزراعة - جامعة طنطا

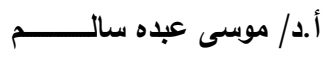


M.A.EI-Bana, et al., 